\title{
Audit Committees, Auditors and Corporate Governance: A Theoretical Bricolage for Epistemological Guidance Correlating with the Indian Context
}

\author{
Padma Srinivasan, Punit Cariappa, M.D.Saibaba
}

\begin{abstract}
The last two decades offer a pantheon of business failures, which drove modern corporate governance reforms, is demanding a strong assurance function, particularly from Auditors. This paper examines both qualitatively and quantitatively the ramifications of interfaces among the corporate triad members-Audit committee, External auditors and Internal Auditors. Focused on the backstage of corporate governance fiascos such as Carrilion, IL\&FS and others, an attempt is made to understand through the Meta study their encumbrance. It is observed from this study is that, while the plethora of reforms are premised on Blue Ribbon Committee's recommendation, Shareholder activism has brought in paradigm changes in the CG landscape, particularly the activities of the committees and the Auditors. The notable one is what we term it as "Carrilion effect". Aftermath of Carrilion's Corporate Governance fiasco, investors are fueling calls for the breakup of the Big 4 audit firms. Another critical observation is that globally, revenue from consulting and advisory services have risen dramatically vis-a vis the marginal increases in audit revenues. It is drawing flak from the investors and regulators. From the flip side perspective, qualitatively in the Indian context, the results of regressions shows that independent audit committees are perceived to be adding value over a short periods of time, as reflected by Tobin's $Q$, a proxy measure of financial performance.
\end{abstract}

Index Terms: Corporate Governance, Audit committees, Auditors, Tobin's Q, Firm performance

\section{INTRODUCTION}

Following a stream of corporate scandals in the early 2000s, US enacted SOX Act, which expanded the responsibilities of audit committees. In particular, the Act empowered ACs directly to engage them and ensure transparent statements and control systems. Moreover, Audit committees are also responsible for the quality of financial reporting and the effectiveness of internal controls. Primarily these were based on the recommendations of BRC and the underlying philosophy of such recommendations was that External auditors will be significant deterrents to earnings management and tunneling. Markets react positively to reports indicating strong oversight, consistent with perceptions of higher financial reporting quality.

Thus the ACs have become critical factor for transparent reporting. However there are instances wherein Audit committees and Auditors were complicit in earnings management resulting in wealth erosion of the shareholders. Following Meta study shows the summary of some of the notable governance fiascos wherein managerial and auditors' involvement was evident. The list of such firms is vast, however for the purposes of brevity and availability of critical information, few of them have been shown without impairing the spirit of the purpose

Meta-study: Brief summary of the corporate governance fiascos which eroded share holders' wealth, significantly.

Table 1: Table shows the list of the firms, its lead Auditors and the brief summary of the crises

\begin{tabular}{|l|l|l|lr|}
\hline $\begin{array}{l}\text { S. } \\
\text { No }\end{array}$ & Firm & $\begin{array}{l}\text { Lead } \\
\text { Auditors }\end{array}$ & \multicolumn{1}{|c|}{ Nature of crisis } \\
\hline 1 & $\begin{array}{l}\text { Carrilion- } \\
\text { UK }\end{array}$ & $\begin{array}{l}\text { KPMG for 19 } \\
\text { years } \\
\text { Deloitte-Inter } \\
\text { nal Auditors }\end{array}$ & $\begin{array}{l}\text { Earnings Management } \\
\text { "traded not certified" } \\
\text { revenue }\end{array}$ \\
\hline
\end{tabular}

Revised Manuscript Received on July 5, 2019.

Dr M.D.Saibaba, Professor, Dayananda Sagar Academy of Technology and Management, Bangalore, India, saibaba11084@gmail.com

Dr. PADMA SRINIVASAN, Director (International Programs) at Indian School of Business and Computing, Bangalore, India

Dean-School of Management- Dayananda Sagar University, Bangalore, India




Audit committees, Auditors and Corporate Governance: A theoretical bricolage for epistemological guidance correlating with the Indian context

\begin{tabular}{|c|c|c|c|}
\hline 2 & IL\&FS & $\begin{array}{l}\text { Deloitte- EY } \\
\text { affiliate } \\
\text { SRBC \& Co, } \\
\text { and KPMG } \\
\text { affiliate BSR }\end{array}$ & $\begin{array}{l}\text { Asset liability mismatch } \\
\text {-Ballooning Debt }\end{array}$ \\
\hline 3 & Satyam & PwC & Tunneling of the funds \\
\hline 4 & Paramalat & $\begin{array}{l}\text { Grant } \\
\text { Thornton }\end{array}$ & $\begin{array}{l}\text { Faking of profits through } \\
\text { creation of shell } \\
\text { companies; Tunneling }\end{array}$ \\
\hline 5 & World.com & Anderson & $\begin{array}{l}\text { Capitalization of operating } \\
\text { costs resulting in fictitious } \\
\text { profits }\end{array}$ \\
\hline 6 & Tyco & $\mathrm{PwC}$ & $\begin{array}{l}\text { Camouflaged the } \\
\text { information pertaining to } \\
\text { loans and borrowings } \\
\text { distorting the financial } \\
\text { costs. }\end{array}$ \\
\hline 7 & Xerox & KPMG & $\begin{array}{l}\text { Adopted "topside } \\
\text { accounting devices" } \\
\text { implying overstating its } \\
\text { true equipment revenues } \\
\text { and its true earnings }\end{array}$ \\
\hline 8 & SHELL & $\begin{array}{l}\text { KPMG } \\
\text { and PwC }\end{array}$ & $\begin{array}{l}\text { Abnormal inflating of oil } \\
\text { and gas reserves thereby } \\
\text { managed the earnings. }\end{array}$ \\
\hline 9 & Enron & Anderson & $\begin{array}{l}\text { Crafted manipulation of } \\
\text { the financial statements. }\end{array}$ \\
\hline \multicolumn{4}{|c|}{$\begin{array}{l}\text { There are also many others who have adopted similar } \\
\text { practices; Hollinger Vivendi, Ahold, Adecco, Kmart, } \\
\text { Global Crossing, Adelphia etc. These companies have } \\
\text { destroyed billions of dollars in shareholder value which } \\
\text { could have been avoided but for the lack of deterrence from } \\
\text { the external Auditors. Besides the above aspects it is } \\
\text { observed that the Audit committee meetings are } \\
\text { qualitatively impaired in such firms. }\end{array}$} \\
\hline
\end{tabular}

Table 2: Number of Audit Committee meetings conducted. Source: AR of a typical company.

\begin{tabular}{|l|l|l|}
\hline $\begin{array}{l}\text { Sl.n } \\
\text { o }\end{array}$ & Name & No of Meetings \\
\hline 1 & Chairman & 5 \\
\hline 2 & Dir1 & 1 \\
\hline 3 & Dir2 & 5 \\
\hline 4 & Dir3 & 1 \\
\hline 5 & Dir4 & 1 \\
\hline
\end{tabular}

From the above table it can be seen that the conduct of the meetings has not been satisfactory, mainly due to the absence of members. In many cases the quorum is maintained but the duration and quality of the meeting is woefully inadequate. It may be noted that both the internal and external auditors are present during such meetings.
At this juncture the perennial question continues "Quis Custodiet Custodes?"(who is to watch the watchdogs). Besides, evidence from the related research shows the lack of critical attributes and credibility of the AC members which sums up the apathy. The attributes are listed below. ((DeZoort, 1997; Guy and Zeff, 2002),

- Independence,

- Financial and operational expertise

- Experience in oversight

Table 3. Table shows the impact of AC's on diligent operations of Firms. (Adapted from Stuart and Mahbub 2004)

\begin{tabular}{|c|c|}
\hline Influence & Exemplar \\
\hline $\begin{array}{l}\text { Tectonic } \\
\text { compensation }\end{array}$ & $\begin{array}{l}>\text { Reduction in Agency costs and } \\
\text { Legal liability of the Directors. } \\
>\text { Analytical rigor adopted in } \\
\text { selection of External Auditors. }\end{array}$ \\
\hline Audit function & $\begin{array}{l}>\text { Scientific design of components of } \\
\text { remuneration system. } \\
>\text { Greater independence to the } \\
\text { Auditors } \\
>\text { Effective review of Red } \\
\text { flags-proper checks and } \\
\text { balances. } \\
>\text { Effective scrutiny of the } \\
\text { Management Accounting and } \\
\text { Control Systems. }\end{array}$ \\
\hline $\begin{array}{l}\text { Financial } \\
\text { reporting quality }\end{array}$ & $\begin{array}{l}>\text { Meaningful review of qualified } \\
\text { audit report. } \\
>\text { Actions initiated to stem the source } \\
\text { of errors in reporting and accounting } \\
\text { policies. } \\
>\text { Legal actions. }\end{array}$ \\
\hline $\begin{array}{l}\text { Corporate } \\
\text { performance }\end{array}$ & $\begin{array}{l}>\text { Shareholders' } \\
\text { management }\end{array}$ \\
\hline
\end{tabular}

It is obvious that there are many instances of friction/collusion among the members resulting in overlooking of wrongdoings.

\section{LITERATURE REVIEW}

Bratten et al. (2019) examine the aspects of AC's oversight. Their findings are obvious; the quality of effective monitoring by AC's precludes earnings management. After SOX Cohen et al.(2010) finds better engagement and knowledge transfer. They observed that when interacting with the external auditor, post-SOX, audit committees were more likely to raise questions about the audit plan, risk assessment, audit outcomes and credibility of financial reports. DeZoort et al. (2002) list four key elements of

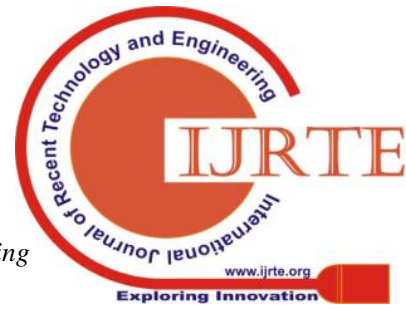


responsible committee: audit composition, authority, resources, and diligence. To supplement this Jean Be'dard et al. (2004) find that effectiveness of these key elements is good deterrents against earnings management. Gosh et al. (2010) find that quantitative aspects such as the size, tenure and activities of the boards and audit committees, can act as credible restraints in earnings management. Shepardson's (2018) study shows that effective audit committees can ensure conservative financial statements and avoid contagious decisions across group firms.

Reid et al. (2018) examine data from the UK where PLC's are required to report about the evaluation of the external audit, as well as appointment or reappointment of the auditor. However they find that requiring disclosure of the audit committee oversight process was not associated with improved audit quality. Contrary to this survey evidence of Christensen et al. (2016) stresses AC's oversight as a critical component of audit process. Agency theory posits dormant role of investors' and information asymmetry are the prime factors for engineered earnings. Disclosures can mitigate these agency problems (Healy and Palepu 2001). Signaling theory (e.g., Spence 1973) suggests asymmetric information can be alleviated by having one party send a signal revealing information to the other party. In the case of audit committees, reports about their activities can reduce information asymmetry pertaining to oversight and financial reporting. Recent research suggests that shareholders are more likely to vote in support of audit committees which ensure transparent reporting (Gal-Or et al. 2017).

\section{METHODOLOGY OF STUDY:}

Meta Study: Methodology is interpretive and archival sourced research. It is adopted to summarize the governance debacles. Data pertains to evidences collected by researchers and the same has been used for Meta study.

Panel data regressions: Pooled, FE and RE regressions reflect space and time dimensions of the variables. Financial data pertaining to listed firms has been regressed against Tobin's Q as. Panel data regressions have the advantages of factoring heterogeneity, and are dynamic. Panel data regressions for the data relates to years 2009-12

Quantitative data comprises of two sets: First one being hand collected from ARs of BSE 200 index companies for the years 2009-12.Second one being financial data of these companies from the prowess for the years 2009-12 and 2016-17

Quantitative analysis: We had studied the companies listed in BSE 200 index for the years 2009-12 for the impact of fully independent audit committees, audit committee meetings on firm performance pertaining to these firms. BSE 200 index represents more than $70 \%$ of the Capitalization. The results of panel data regressions for the years 2009-12 have been incorporated which shows that firms with full independent audit committees are accorded premium valuations by the investors. Subsequently the data pertaining to the audit committees has been regressed with financial data of 2015 to ascertain whether the independence has strategic orientation. The study covers 744 firm years, over a period of 4yrs from 2009 to 12.The results based on panel data regressions indicate that audit committee's independence has significant positive association with $\mathbf{Q}$

Literature review: Bratten et al. (2019) examine the aspects of AC's oversight. Their findings are obvious; The quality of effective monitoring by AC's precludes earnings management. After SOX Cohen et al.(2010) finds better engagement and knowledge transfer. They observed that when interacting with the external auditor, post-SOX, audit committees were more likely to raise questions about the audit plan, risk assessment, audit outcomes and credibility of financial reports. DeZoort et al. (2002) list four key elements of responsible committee: audit composition, authority, resources, and diligence. To supplement this Jean Be'dard et al. (2004) find that effectiveness of these key elements are good deterrents against earnings management. Gosh et al.(2010) find that quantitative aspects such as the size, tenure and activities of the boards and audit committees, can act as credible restraints in earnings management. Shepardson's(2018) study shows that effective audit committees can ensure conservative financial statements and avoid contagious decisions across group firms. Reid et al. (2018) examine data from the UK where PLC's are required to report about the evaluation of the external audit, as well as appointment or reappointment of the auditor. However they find that requiring disclosure of the audit committee oversight process was not associated with improved audit quality. Contrary to this survey evidence of Christensen et al.(2016) stresses AC's oversight as a critical component of audit process. Agency theory* posits dormant role of investors' and information asymmetry are the prime factors for engineered earnings. Disclosures can mitigate these agency problems (Healy and Palepu 2001). Signaling theory (e.g., Spence 1973) suggests asymmetric information can be alleviated by having one party send a signal revealing information to the other party. In the case of audit committees, reports about their activities can reduce information asymmetry pertaining to oversight and financial reporting. Recent research suggests that shareholders are more likely to vote in support of audit committees which ensure transparent reporting (Gal-Or et al. 2017).

\section{Methodology of study:}

Meta Study: Methodology is interpretive and archival sourced research. It is adopted to summarize the governance debacles. Data pertains to evidences collected by researchers and the same has been used for Meta study.

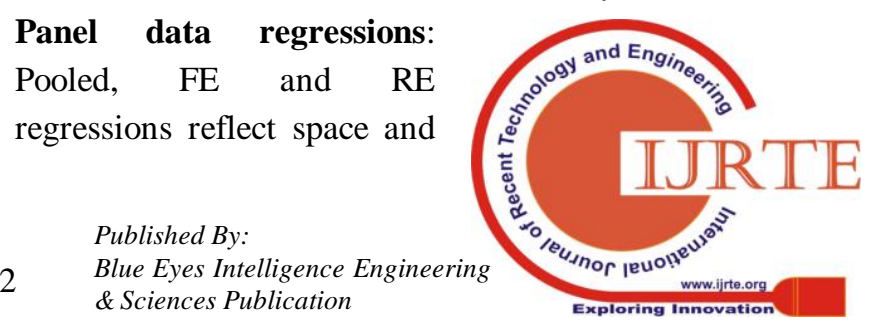




\section{Audit committees, Auditors and Corporate Governance: A theoretical bricolage for epistemological guidance correlating with the Indian context}

time dimensions of the variables. Financial data pertaining to listed firms has been regressed against Tobin's Q as. Panel data regressions have the advantages of factoring heterogeneity, and are dynamic. Panel data regressions for the data relates to years 2009-12

Quantitative data comprises of two sets: First one being hand collected from ARs of BSE 200 index companies for the years 2009-12 .Second one being financial data of these companies from the prowess for the years 2009-12 and 2016-17.

Quantitative analysis: We had studied the companies listed in BSE 200 index for the years 2009-12 for the impact of fully independent audit committees, audit committee meetings on firm performance pertaining to these firms. BSE 200 index represents more than $70 \%$ of the Capitalization.

The results of panel data regressions for the years 2009-12 have been incorporated which shows that firms with full independent audit committees are accorded premium valuations by the investors. Subsequently the data pertaining to the audit committees has been regressed with financial data of 2015 to ascertain whether the independence has strategic orientation. The study covers 744 firm years, over a period of 4yrs from 2009 to 12. The results based on panel data regressions indicate that audit committee's independence has significant positive association with $\mathbf{Q}$.

\section{Conclusion}

Till recent times engaging Big Auditing firms has been considered as a premium attribute by the researchers, investors and other stakeholders, as well. Post Carrilion there is a paradigm shift in the perception of external stakeholders. While Enronitis led to the dismantling of Anderson, the Carrilion effect is fueling calls for dismantling of the remaining. This is primarily because of the role of external auditors, who are expected to play a critical role as watchdogs of corporate governance systems and they are not doing so, effectively. Investors also expect them to play a significant deterrent role against ruination. However the role of the AC's and Auditors in Corporate Governance fiascos is belling and contrary to their expectations.

The study finds, that while many Audit firms are doing this role effectively, some major scandals are casting a serious doubt on efficacy and reliability of these audit firms, particularly the Big reputed Auditing firms. This is in consonance with the findings of the other researchers. This calls for refinements in reporting process without stymieing the performance of genuine firms.

The caveats are that of the limitations in the spectrum of firms and the time period precludes generalization.

\section{REFERENCES}

1. Aloke Ghosh, Antonio Marra Doocheol Moon (2010), Corporate Boards Audit Committees, and Earnings Management: Pre and Post SOX Evidence Overseeing the External Audit Function:Evidence from Audit Committees'

ReportedActivities;https://doi.org/10.1111/j.1468-5957.2010.02218 37(9), 1145-1176.

2. Blue Ribbon Committee (1999), "Report And Recommendations of the Blue Ribbon Committee on Improving the Effectiveness of Corporate Audit Committees", The New York Stock Exchange and the National Association of Securities Dealers, New York.

3. Bratten, B., Payne, J. L., \& Thomas, W. B. (2016). Earnings management: Do firms play "follow the leader"? Contemporary Accounting Research, 33(2), 616-643.

4. Bratten, B., Causholli,M., \& Sulcaj,V. (2019).Overseeing the external audit function: Evidence from audit committees' reported activities. SSRN 3314334 - papers.ssrn.com

5. Christensen, B. E., S. M. Glover, T. C. Omer, and M. K. Shelley. (2016). Understanding audit quality: Insights from audit professionals and investors. Contemporary Accounting Research, 33 (4), 1648-1684.

6. Cohen, J. R., U. Hoitash, G. Krishnamoorthy, and A. M Wright. (2014).The effect of audit committee industry expertise on monitoring the financial reporting process. The Accounting Review 89 (1), 243-273.

7. Cohen, J.,G. Krishnamoorthy, and A. Wright (2010). Corporate governance in the post-Sarbanes-Oxley era: Auditors' experiences. Contemporary Accounting Research 27 (3), 751-786.

8. DeZoort, F.,Todd Dana, R., Hermanson, B and Richard, W.Houstona.(2002).Audit committee support for auditors: The effects of materiality justification and accounting precision, Journal of Accounting and Public Policy, 22 (2), 175-199

9. DeZoort, F.,Todd,Dana, R., Hermanson, Deborah, S. Archambeault, and Scott A. Reed.(2006). Audit Committee Effectiveness: A Synthesis of the Empirical Audit Committee Literature, Journal,21(1),38-75

10. Fama, E. F., and M. C. Jensen. 1983. Separation of ownership and control The Journal of Law \& Economics 26 (2), 301-325.

11. Gal-Or, R., R. Hoitash, and U. Hoitash.(2017).Shareholder elections of audit committee members: A Journal of Practice \& Theory (forthcoming)

12. Healy, P. M., and K. G. Palepu.(2001). Information asymmetry, corporate disclosure, and the capital markets: A review of the empirical disclosure literature. Journal of Accounting and Economics 31 (1), 405-440.

13. Jean Be'dard, Sonda, C., and Lucie, C. (2004).The Effect of Audit Committee Expertise, Independence, and Activity on Aggressive Earnings Management. AUDITING: A Journal of Practice \& Theory, 23(2), 13-35.

14. Cohen,J.,Ganesh.K.,Wright.A.M.(2010).Corporate Governance and the Audit Process .Contemporary Accounting research,19,(4), 573-594

15. Jensen, M. C., and W. H. Meckling. (1976). Theory of the firm: Managerial behavior, agency costs and ownership structure. Journal of Financial Economics 3 (4), 305-360.

16. Reid, L. C., J. V. Carcello, C. Li, and T. L. Neal. (2018). Impact of auditor and audit committee report changes on audit quality and costs: Evidence from the United Kingdom. Contemporary Accounting Research (Forthcoming).

17. Spence, M. (1973). Job market signaling. The quarterly journal of Economics 87 (3):355-374.

18. Shepardson, Marcy L. (2018).Accounting, Organizations and Society Effects of individual task-specific experience in audit committee oversight of financial reporting outcomes https://doi.org/10.1016/j.aos

19. Turley,S.,and M. Zaman, (2003), Public Policy on Corporate Audit Committees: Case Study Evidence of Current Practice. Occasional Research Paper No. 35, Association of Chartered Certified Accountants, London. 


\section{AUTHORS PROFILE}

Dr. PADMA SRINIVASAN, PhD is now serving as Director (International Programs) at Indian School of Business and Computing, Bangalore, India. She has 32 years of experience working as Compliance Consultant and as a Professor of B Schools in India. She has been active researcher in the areas of Accounting and Asset Accountability and Corporate Governance.



Dean-School of Management- Dayananda Sagar University: Guest faculty for executive programs at IIM-B; Professional Associations: S.P.Jain, Singapore- Course on Financial Statements Analysis for Executive MBA; Symbiosis - M \& A course for EMBA, and FA and MA courses under Corporate Programs for Bosch, Cegedim, IBM, HP, Wipro and Dr.Reddys Lab; TAPMI (Bangalore) -Financial Accounting and Management Accounting for Oracle Direct Programs: Jain University- Course on Financial accounting, Management accounting, corporate finance and corporate restructuring.

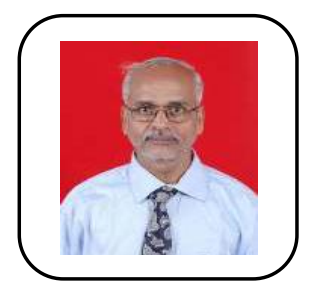

Dr M.D.Saibaba, Professor, Dayananda Sagar Academy of Technology and Management, Fellow of ICMAI and MIE .E mail: saibaba11084 @ gmail.com 